\title{
The Evaluation of the Implementation of Preceptorship Model Training In Blud RSUD Nabire with Kirkpatrick Approach
}

\author{
Wibowo Hanafi Ari Susanto ${ }^{1}$, Titih Huriah², Moh Afandi ${ }^{2}$
}

\author{
${ }^{1}$ Student of Master Program of Nursing of Muhammadiyah University of Yogyakarta \\ ${ }^{2}$ Master of Postgraduate Program of Nursing of Muhammadiyah University of Yogyakarta \\ Integrated Campus UMY Jl. Lingkar Selatan, Tamantirto, Bantul Yogyakarta 55183 \\ *Email: wibowohanafi@gmail.com
}

\begin{abstract}
Abstrak
Model preceptorship adalah sistem pembelajaran berkelanjutan yang melibatkan peran perawat sebagai panutan dan siswa dalam pengaturan klinis, tujuan pembelajaran model preceptorship adalah membentuk siswa menjadi perawat profesional, memiliki rasa tanggung jawab penuh dan berpengetahuan, sehingga akan dapat meningkatkan kualitas perawat terutama dalam pengaturan klinis yang dibuktikan dengan akuntabilitas dalam pekerjaan, kompetensi, komunikasi terapeutik dalam pengaturan klinis. Pelatihan preceptorship adalah kegiatan untuk meningkatkan pengetahuan guru tentang pengembangan ilmu keperawatan sehingga dapat diterapkan di lapangan praktik atau proses bimbingan. Efektivitas program pelatihan dapat dievaluasi pada proses pelatihan. Mengevaluasi program pelatihan adalah tahap terakhir dalam pelatihan itu sendiri. Kirkpatrick membagi empat level dalam mengevaluasi proses. Ada reaksi, pembelajaran, perilaku dan hasil pelatihan. Untuk menganalisis evaluasi pelaksanaan pelatihan model preceptorship di BLUD RSUD Nabire dengan pendekatan Kirkpatrick. Metode penelitian yang digunakan adalah deskriptif kuantitatif. Total ukuran sampel adalah 14 responden dengan teknik total sampling. Responden diberikan intervensi berupa pelatihan model preceptorship. Tingkat reaksi menunjukkan reaksi positif yang tinggi terhadap pelatihan sebesar $86,83 \%$, tingkat pengetahuan menunjukkan peningkatan pada pengukuran ketiga dengan kategori baik $100 \%$ dan sikap menunjukkan kategori positif $100 \%$, tingkat perilaku menunjukkan penerapan pembelajaran dalam kategori baik 71, 4\% dan tingkat hasil menunjukkan hasil B $+50 \%$. Ada pengaruh pelaksanaan pelatihan Model Preceptorship pada reaksi, pembelajaran, perilaku dan hasil. Diharapkan bahwa metode pembelajaran klinis dapat diintegrasikan ke dalam kurikulum pendidikan keperawatan.
\end{abstract}

\section{Kata kunci : Kirkpatrick, Model Precepthorship, Pelatihan}

\begin{abstract}
Preceptorship model is a continuous learning system that involves the role of nurses as role models and students in the clinical setting, the goal of preceptorship model learning is to form students to become professional nurses, having full sense of responsibility and knowledgeable, so that it will be able to improve the quality of nurses especially in the clinical setting as evidenced by accountability in the work, competence, therapeutic communications in the clinical setting. Preceptorship training is an activity to improve preceptor knowledge about nursing science development so that it can be implemented on the practice ground or guidance process. The effectiveness of a training program can be evaluated in the training process. Evaluating the training program is the last stage in the training itself. Kirkpatrick divides four levels in evaluating the process. There are a reaction, learning, behavior, and result of training. To analyze the evaluation of the implementation of the preceptorship model training at the BLUD RSUD Nabire with a
\end{abstract}


Kirkpatrick approach. The research method used was descriptive quantitative. The total sample size was 14 respondents with a total sampling technique. Respondents were given intervention in the form of training of the preceptorship model. The reaction level showed a high positive reaction to the training of $86,83 \%$, Knowledge level showed improvement in the third measurement with a good category of $100 \%$ and attitude showed a positive category of $100 \%$, behavior level showed the implementation of learning in a good category of $71,4 \%$ and the result level showed the result of $B+$ of $50 \%$. There was an influence of the implementation of Preceptorship Model training on reaction, learning, behavior, and result. It was expected that clinical learning method could be integrated into the nursing education curriculum.

Keywords: Kirkpatrick, Precepthorship Model, Training

Article info:

Article submitted on September 18, 2018

Articles revised on October 16, 2018

Articles received on November 14, 2018

DOI: $h$ ttp://dx.doi.org/10.21927/jnki.2018.6(3).203-210

\section{INTRODUCTION}

The learning process at the nursing institution has four important components where learning is carried out in classes, laboratories, clinics and communities. Learning in the clinic is the essence of learning of the Diploma III in Nursing, learning in the clinic can form professional nurses in which to educate objectively and shape the characteristics of the individual in the future (1).

Learning in the clinic area allows learners to apply theoretical knowledge in true nursing actions. A conducive clinical learning environment is a dynamic place with good resources for students, the selected clinical environment is essential to achieve the objectives and goals of clinical practice in a nursing education program so that it can improve cognitive, affective and psychomotor (2).

Preceptorship model is a continuous learning system that involves the role of nurses as role models (preceptor) and students (preceptee) in the clinical setting, the objective of learning in a preceptorship model is to form students to become professional nurses, having full sense of responsibility and knowledgeable so that it will be able to improve the quality of nursing, especially in the clinical setting as evidenced by accountability in work, competence, therapeutic communications in the clinical setting (3).

BLUD (Regional Public Service Agency) of RSUD (Regional public hospital) of Nabire is the only hospital in Nabire Regency, BLUD RSUD Nabire is a home base of clinical practice of the Diploma III program in Nursing in Nabire. The results of interviews with some preceptors at BLUD RSUD Nabire said that there has never been any training related to preceptorship model, the implementation of the guidance was only inherited from the previous seniors and did not know the correct theory of guidance model to students.

The solution to that problem is how to produce preceptor that has competence so that it can change the cognitive, affective and psychomotor of the student by giving the training of the preceptorship model. With the training of preceptorship model, it is expected that the preceptors will get the development of nursing science so that they can implement on the ground or in the process of providing guidance to the students (4). 
To know the effectiveness of a training program, evaluation can be conducted in the training program. Evaluating the training program is the last stage in the training itself because by conducting an evaluation of the training program, we can see how well the training objectives have been fulfilled and whether the training method has reached the objectives.

According to Kirkpatrick, four levels in evaluating a training are 1) reaction; 2) learning; 3) behavior; 4) result. The first stage evaluation is to assess the participants' reactions after being trained, the second stage is to assess the participants' knowledge and attitude before and after the training, the third stage is to assess the behavior toward materials obtained during the training and the last stage is to assess the impact or results (5).

With so many problems encountered such as the absence of the nurse's role model and unclear clinical learning model, the ratio of students and mentors that is too much. The program of the preceptorship model is very important to be applied in the clinic area, there are many benefits that can be learned such as creating a qualified nurse in nursing service, can adopt new nurse, improving the quality of guidance of the students, facilitating the method of learning and assessment then researchers are interested in doing a research about "Evaluation of Implementation of Preceptorship Model Training of in BLUD RSUD Nabire Using Kirkpatrick Approach".

\section{MATERIALS AND METHODS}

The research method used was a descriptive quantitative, this research was conducted in April-June 2018. The sample used was all of the preceptors of RSUD Nabire that would become the preceptors on Clinical Practices of Basic Nursing of 14 people with the sampling technique used was total sampling. The respondents were given intervention in the form of training of the preceptorship model.

\section{RESULTS AND DISCUSSION}

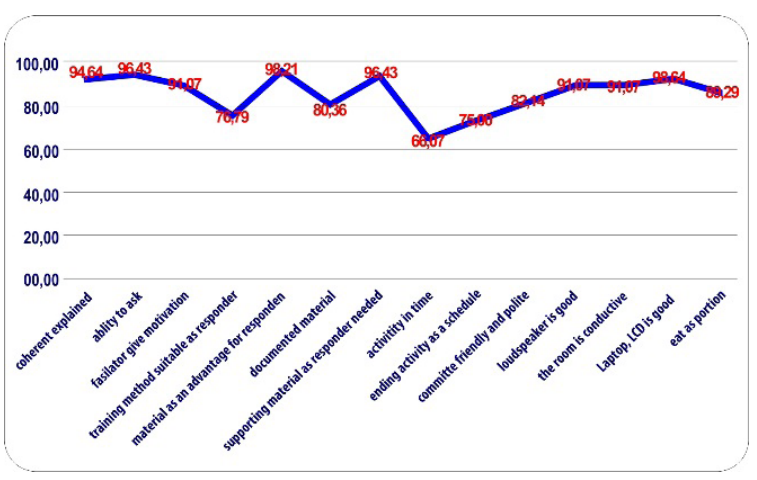

Figure 1 Response of respondents to the training implementation $(n=14$ people)

Figure 1 shows that in the respondent's reaction to the implementation of the training of preceptorship model, the most reaction percentage is on the items of training materials is in accordance with the needs of respondents of $98.21 \%$, able to answer respondents' questions and training materials support respondents needs of $96.43 \%$, while the minority is on the item of activity is conducted on time of $66.07 \%$.

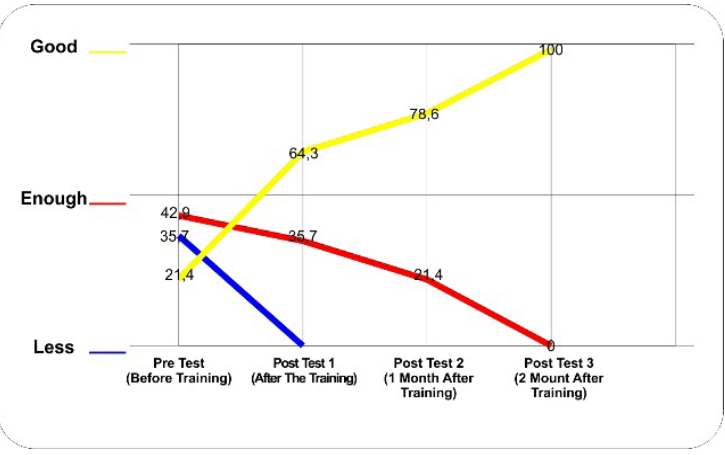

Figure 2 Distribution of respondents' knowledge before and after training of the preceptorship model ( $n=14$ people)

From Figure 2 the results show that there is a difference or increase of knowledge before and after training. Before the training is conducted, the knowledge of the respondents is mostly in the fair category of $42.9 \%$, after the training in posttest 1 , most of the respondents are in a good category of $64.3 \%$, in posttest 2 , most of the respondents are in a good category of $78.6 \%$, while for posttest 3 , most of the respondents are in a good category of $100 \%$. 


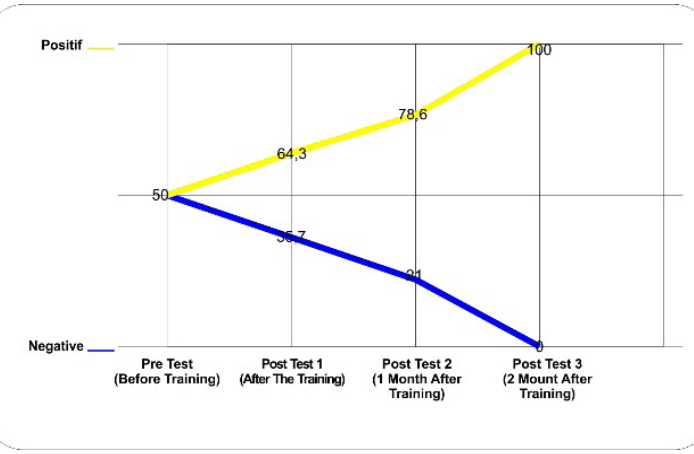

Figure 3 Distribution of respondents' attitude before and after the training of the preceptorship model ( $n=14$ people)

Based on figure 3 , it is found that there are differences or improvements in the attitude before and after training. Before the training, respondents' attitudes have similar categories of negative or positive of 7 respondents (50\%). After the training, on posttest 1 most of the respondents are in a positive category of 9 respondents (64.3\%). In posttest 2 , most of the respondents are in a positive category of 11 respondents $(78.6 \%)$, while for posttest 3 , most of the respondents are in a good category of 14 respondents $(100 \%)$

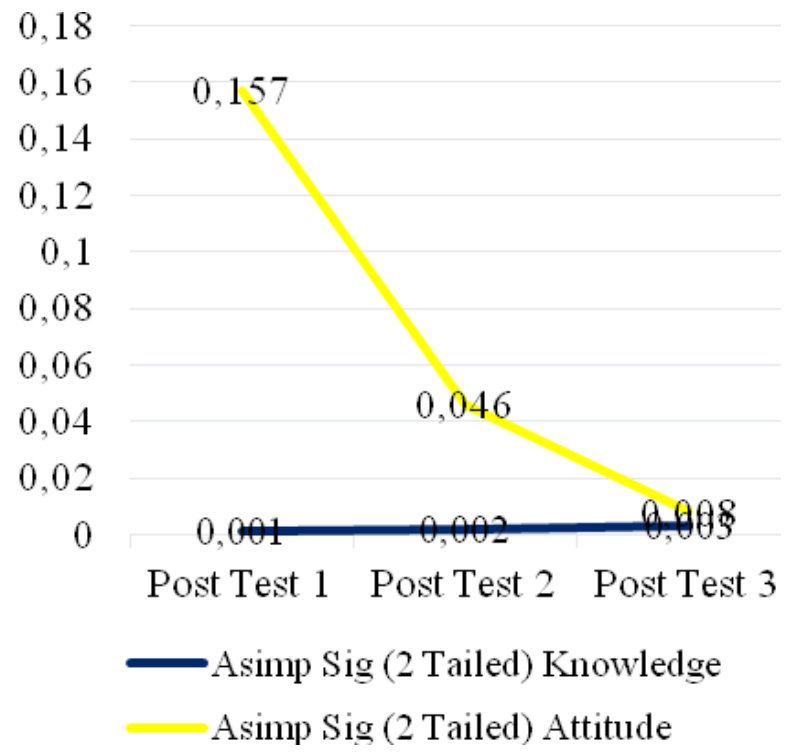

Figure 4 Wilcoxon test results on knowledge and attitude before and after the training of preceptorship model

The statistic test results of Wilcoxon test from 3 times measurements after training from 14 respondents in the knowledge variable, it is found that the highest value of Asimp Sig (2 tailed) is
0.003 in post-test 3 , in the attitude variable, it is found that the highest value of Asimp Sig (2 tailed) is in post-test 1 of 0.157

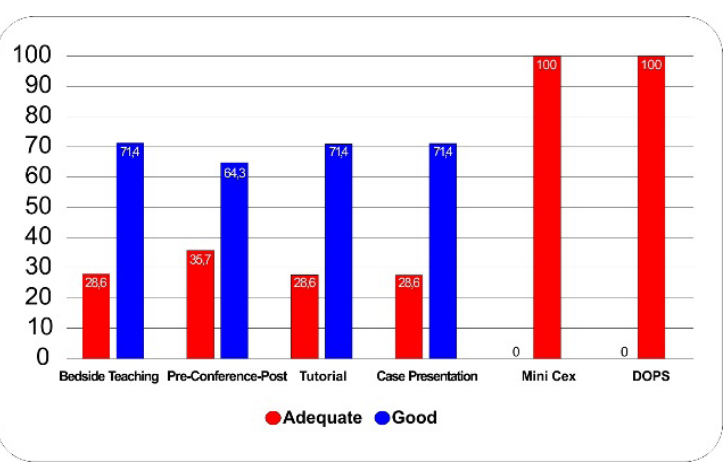

Figure 5 Implementation of the learning method of the preceptorship model for second Semester students of Diploma III program in Nursing in Nabire

In the figure, it is obtained that in the implementations of bedside teaching, tutorials, case presentation, the respondents are in a good category of 10 people $(71.4 \%)$, In the implementation of the conference, the respondents are in a good category of 9 people $(64.3 \%)$, in the implementations of mini cex (Checklist) and DOPS assessment, the respondents are in a good category of 14 people $(100 \%)$.

Table 1. Results of the implementation of the preceptorship model of the second-semester students of Diploma III program in Nursing in Nabire

\begin{tabular}{ccc}
\hline Assessment & $\mathbf{F}$ & $\%$ \\
\hline A & 1 & 2.9 \\
A- & 17 & 20.6 \\
B+ & 34 & 50.0 \\
B & 14 & 20.6 \\
B-/C/D & 2 & 2.9 \\
\hline
\end{tabular}

Based on the table above, the implementation of the preceptorship model to the secondsemester students is mostly in the category of $\mathrm{B}+$ of 34 people $(50 \%)$.

\section{DISCUSSION}

\section{Reaction level}

Based on the results of the evaluation that has been done, it was found that the reaction of the respondents in the training showed a high 
positive reaction result of $86,83 \%$. In addition, from these results, it can be seen the positive reaction emerged from the positive reaction of respondents that came from 4 components assessed such as resource persons, materials, facilities, and infrastructure and implementation. The respondent's reaction to the function of the training that is in accordance with the respondent's needs showed a very high percentage of $98.21 \%$ but the lowest reaction was in the implementation of preceptorship activities, especially in terms of timeliness of the implementation, which only showed a percentage of $66 \%$.

This is supported by the study (Dorri et al., 2016) which suggests that the training that is given demonstrates a positive role in improving human resource capacity within an organization. In the reaction level, respondents showed positive results and feedback and a strong desire to participate in the training because the training given was considered to be profitable, related and relevant to the work they were doing. Meanwhile, according to Wilson et al. (2013), they state that the training of the preceptorship model given to the respondents shows a high positive reaction level. Most of the respondents had a level of confidence in the training of the preceptorship model using simulation-based education for clinical or skill learning that was a very effective strategy.

According to Kertis (2007), he states that initially, the role of the preceptor is only as an educator, role model, and socializer. However, to become an excellent clinician, the role and responsibility of the facilitator are not only in that scope, a facilitator must also become an evaluator, leader, and protector. Preceptor really needs knowledge of adult learning principles, how to develop critical thinking skills in practice and how to provide constructive feedback. Therefore, the provision of training with emphasizing on the importance of the preceptor role and the preceptorship learning method is expected to increase the positive reaction to the training that is provided.

The reaction level of this training includes the methods used, the ability of the speaker in delivering the material, the existing training facilities, as well as some aspects to see the reaction level of the respondents during the training. However, if it is analyzed in more detail, from the results of each component, there are some aspects of training that still need to be improved such as the timeliness of the implementation of training $(66,07 \%)$ or the end of activities that tend not to match the schedule set and training methods provided shall be adjusted to the characteristics of the respondents so that the positive reaction or the reaction level of respondents to the quality of training can be improved. In accordance with Lahti (2014), it is important to measure the participants' reactions by looking at each of the components that are measured, each of the participants is strongly emphasized to provide an honest and objective assessment of reaction. Because of any reaction that arises, it will largely determine the extent to which a participant can confront and engage in an ongoing educational program or activity. In this case, poor reactions to the implementation of an activity that is not timely conducted can be a suggestion for quality improvement.

\section{Learning level}

Based on the results of evaluations that have been done, the level of learning showed an increase in knowledge and attitudes of respondents. The measurement of knowledge and attitudes was performed 4 times, the first measurement was conducted before the training activity started that was on April 17, 2018, it was found that most of the respondents' knowledge was in a fair category of $42.9 \%$ and the attitude of the respondent was both in positive and negative categories of $50 \%$. Meanwhile, the second measurement conducted after the training that 
was on April 18, 2018, it was obtained that most of the knowledge of respondents were in a fair category of $64.3 \%$ and the attitude was in a positive category of $64.3 \%$. The third measurement conducted 1 month after the training that was on May 14, 2018, it was found that some of the knowledge of the respondents was in a fair category of $78.6 \%$ and the attitude was in a positive category of $78.6 \%$. Meanwhile, the fourth measurement was conducted after the implementation of the second semester students practice using the preceptorship model that was on June 4, 2018, it was found that some of the knowledge of the respondents was in a fair category of $100 \%$ and the attitude of the respondents was in a positive category of $100 \%$.

These results are in accordance with Arbabi, et al. (2018), who state that preceptorship is a program that is vital to develop new nurses. However, in performing its role, preceptor often encounters challenges such as a preceptor must understand how to do an evaluation, give feedback and a preceptor needs knowledge and skill that are useful in dealing with situation and conflict. The most appropriate strategy to achieve that thing is to maximize preceptor preparation and clinical experience with strong support from the organization. Preceptorship training can improve the level of preceptor's readiness and preceptee's satisfaction with the preceptor. Preceptees tend to feel more comfortable with the applied clinical learning process and their stress levels are decreasing. However, preceptorship is basically a continuous and sustainable process, so it requires strong support, up to date learning and ongoing evaluation.

According to Badu (2013), he states that learning is the level of attitude changes, increased knowledge, and skills. Changes in attitude at the learning stage are different from the changes in attitude at the level of behavior. The attitude changes at the learning level are focused on changing attitudes of respondents during training and because training activities are given. Whereas, knowledge is defined as the level of understanding of respondents or participants to the information and learning materials that are given so that the learning objectives can be achieved.

\section{Behavior level}

The behavioral stage showed the results of the implementation of the preceptorship model by the respondents who have attended the training, in the implementation, there were several methods of preceptorship learning including bedside teaching, tutorial and case presentation and most of the respondents were in a good category of $71.4 \%$, in the conference, most of the respondents were in a good category of $64.3 \%$. Meanwhile, in Mini Cex and DOPS assessment, some of the respondents were in a good category of $100 \%$.

The evaluation of this behavior level is a new application of knowledge and skills that are then implemented into the work of each respondent. There are some things that must be there so that the behavioral changes can happen, those are someone must have a strong desire to change, have a good understanding of what to do and how the best strategy to do that, a supportive environment and a reward for positive results (6).

At level 3 of this study, the aspects of behavior that the researchers focus on are the implementation of the role of preceptor and the implementation of learning of the preceptorship model. From the several components, some of the aspects could be implemented well like BST, case presentation, Mini Cex and DOPS Assessment in which all of the respondents were in a good category of $100 \%$. However, in some other aspects such as the implementation of the Conference, Tutorial, it still could not be applied well by some respondents. There are several things that may 
be the cause or obstacle in the application of preceptorship by some preceptor, that is preceptor serves dual position, feel that the method used is new so that it is not maximal yet, lack of room or place to support the tutorial activity. Although there are obstacles, based on the analysis, the success of training at this level was quite maximal or good. This was because the implementation of preceptorship was fully supported by existing organizational structures and preceptor had a strong motivation and commitment to learn and change. In addition, the good results at level 3 were supported by good results at the level or transfer of knowledge at level 2 so that the behavioral changes can occur.

\section{Level of results}

In stage 4 or level of results, it showed the results of all preceptorship learning activities such as BST, conferences, tutorials, case presentation, minicex, dops, of which the scores were taken after the students have completed clinical practices of basic nursing for 3 weeks. From 68 students who followed the clinical practice and did weekly rotation, then it was found that the value of the clinical practice of basic nursing of second-semester students of Diploma III program in Nursing in Nabire was mostly in the value of "B+" of $50 \%$.

This result is supported by Farja's (2012) study that states that there are very effective impacts of preceptorship training on 4 levels, those are knowledge, skills, attitudes and performance behaviors that then improve individual impacts such as learning outcomes and the global impact such as changes to the organizational structure. The objective of the evaluation at this level is to provide a realistic description of the result for the organization to the training that has been done. Nevertheless, even in some implementations of training, usually short-term effects are not directly visible, but it will appear or change over time and give long-term effect. Therefore, although evaluation at the level of the result did not indicate a significant increase in the result, it did not mean that the training given has failed or unsuccessful.

\section{REFERENCES}

Nursalam, N., \& Efendi, F. (2008). Pendidikan Dalam Keperawatan. Retrieved from http://ners.unair.ac.id/materikuliah/BUKUPENDKEPRAWATAN-2008.pdf

Emilia ,O, (2008) Tehnik Dasar Pembimbingan Dalam Pembimbingan Klinik. Bagian pendidikan kedokteran Fakultas Kedokteran Universitas Gajah Mada Yogyakarta.

Omer, Suliman, et al. (2013). "Perception of Nursing Students to Two Models of Preceptorship in Clinical Training." Nurse Education In Practice [Nurse Educ Pract] 13(3): 155-60.

Okoronkwo, I. L., Onyia-Pat, J., Agbo, M. E., Okpala, P. U., \& Ndu, A. C. (2013). Students' perception of effective clinical teaching and teacher behaviour. Open Journal of Nursing, 3(March), 63-70. https://doi.org/10.4236/ ojn.2013.31008

Farjad, S. (2012). The Evaluation Effectiveness of training courses in University by Kirkpatrick Model ( case study : Islamshahr university ), 46, 2837-2841. https://doi.org/10.1016/j. sbspro.2012.05.573

Rouse, D. N. (2011). Employing Kirkpatrick's evaluation framework to determine the effectiveness of health information management courses and programs. Perspectives in health information management, 8(Spring).

Ansari, A. Al, Ali, S. K., \& Donnon, T. (2013). The Construct and Criterion Validity of the Mini-CEX: A Meta-Analysis of the Published Research, 88(3), 1-9. https://doi.org/10.1097/ ACM.0b013e318280a953

Badu, S. Q. (2013). The Implementation of Kirkpatrick â€ $€^{\mathrm{TM}} \mathrm{s}$ Evaluation Model in the 
Learning of Initial Value and Boundary Condition Problems, 3(5), 74-88. https://doi. org/10.5296/ijld.v3i5.4386

Barbara Penprase, RN, PhD, MSN, CNOR. (2012). Perceptions, Orientation, and ransition Into Nursing Practice of Accelerated SecondDegree Nursing Program Graduates. J Contin Educ Nurs;43(1):29-36.

Chen, Y., Duh, Y., Feng, Y., \& Huang, Y. (2011). Preceptors 'Experiences Training New Graduate Nurses: A Hermeneutic Phenomenological Approach, 19(2). https:// doi.org/10.1097/JNR.0b013e31821aa155

Dorri, S., Akbari, M., \& Sedeh, M. D. (2016). Kirkpatrick evaluation model for in-service training on cardiopulmonary resuscitation, 493-497. https://doi.org/10.4103/17359066.193396

Harteis, C., Billett, S., Goller, M., Rausch, A., \& Seifried, J. (2015). Effects of age, gender and occupation on perceived workplace learning support. International journal of

Helminen, K., Tossavainen, K., \& Turunen, H. (2014). Assessing clinical practice of student nurses: Views of teachers, mentors and students. Nurse Education Today, 34(8), 1161-1166. https://doi.org/10.1016/j. nedt.2014.04.007

Kim, K. H., Young Lee, A., Eudey, L., \& Wong Dea, M. (2014). Improving Clinical Competence and Confidence of Senior Nursing Students through Clinical Preceptorship. International Journal of Nursing, 1(2), 183-209.

Konya, V., Matić, D., \& Pavlović, J. (2016). The influence of demographics, job characteristics and characteristics of organizations on employee commitment. Acta Polytechnica Hungarica, 13(3), 119-138.

Kertis, M. (2007). The one-minute preceptor: A five-step tool to improve clinical teaching skills. Journal for Nurses in Professional Development, 23(5), 238-242.
Kristofferzon, M. L., Mårtensson, G., Mamhidir, A. G., \& Löfmark, A. (2013). Nursing students' perceptions of clinical supervision: The contributions of preceptors, head preceptors and clinical lecturers. Nurse Education Today, 33(10), 1252-1257. https://doi.org/10.1016/j. nedt.2012.08.017

Lalonde, M., \& McGillis Hall, L. (2017). The socialisation of new graduate nurses during a preceptorhip programme: strategies for recruitment and support. Journal of Clinical Nursing, 26(5-6), 774-783. https://doi. org/10.1111/jocn.13563

Madhavanpraphakaran, G. K., Shukri, R. K., \& Balachandran, S. (2014). Preceptor' Perceptions of Clinical Nursing Education. The Journal of Continuing Education in Nursing, 45(1), 28-34. https://doi. org/10.3928/00220124-20131223-04

Mohamed-Nabil Ismail, L., Mohamed-Nabil Aboushady, R., \& Eswi, A. (2016). Clinical instructor's behavior: Nursing student's perception toward effective clinical instructor's characteristics. Journal of Nursing Education and Practice, 6(2). https://doi.org/10.5430/ jnep.v6n2p96

Moldovan, L. (2016). Training Outcome Evaluation Model. Procedia Technology, 22(October 2015), 1184-1190. https://doi.org/10.1016/j. protcy.2016.01.166

Rahimi, M. (2013). Is training student reviewers worth its while? A study of how training influences the quality of students' feedback and writing. Language Teaching Research, 17(1), 67-89. https://doi. org/10.1177/1362168812459151

Watkins, C., Hart, P. L., \& Mareno, N. (2016). The effect of preceptor role effectiveness on newly licensed registered nurses' perceived psychological empowerment and professional autonomy. Nurse Education in Practice, 17, 36-42. https://doi.org/10.1016/j. nepr.2016.02.003 